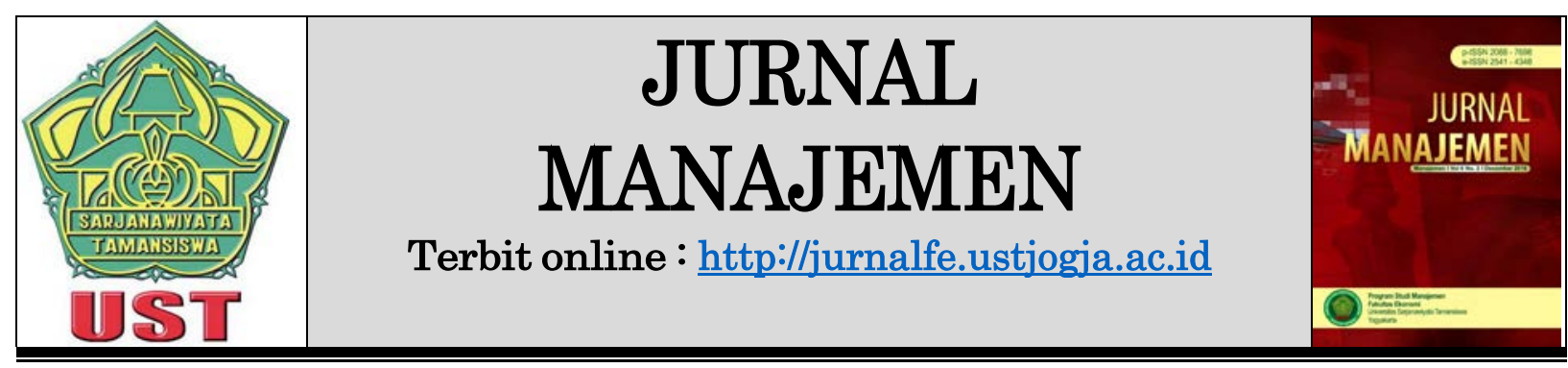

\title{
DAMPAK PENGENDALIAN KUALITAS PRODUKSI DAN PENGEMBANGAN PRODUK GAMBIR DALAM PENINGKATAN KEPUASAN KONSUMEN PADA UNIT USAHA JASA DAN INDUSTRI ANDALAS FARMA
}

\author{
Febriani $^{1}$ \\ Widiya Rahmawati ${ }^{2}$ \\ Hafrizal Okta Ade Putra ${ }^{3}$ \\ ${ }^{123}$ Universitas Tamansiswa Padang \\ Korespondensi: anifebri173@gmail.com
}

\begin{tabular}{lc}
\hline Informasi Naskah & Abstrak \\
\hline Diterima: & Gambir (Uncaria gambir (Hunter) is an export commodity \\
06 September & which plays an important role in enhancing national industrial \\
Revisi: & development. Quality and development of Gambir products \\
11 Oktober & needs to be improved to increase customer satisfaction and \\
Terbit: & maintain the company's position as an innovator and existing \\
16 Desember & market share. to find out how the impact of the quality of \\
\hline Kata Kunci: Gambir, & production and gambir product development in increasing \\
Quality,Development & consumer satisfaction in the Andalas Farma Service and \\
& Industry Business Unit. \\
& This research is qualitative research, the sample in this \\
& study was divided into two objects namely internal and \\
& external data collection techniques used are observations, \\
& interviews and documentation. \\
& The results showed that the impact of the quality of \\
& production and product development of gambir in increasing \\
& customer satisfaction in the Andalas Farma Service and \\
Industry Business Unit was that gambir production in the & business unit services and industry of Andalas Farma have \\
good quality. Good quality can be seen from the production \\
process, the tools used and the results obtained are quite good. \\
While the development of gambir products is that gambier is \\
not only a medicine but also as a cosmetic ingredient.
\end{tabular}

\section{PENDAHULUAN}

Gambir di Sumatera Barat merupakan komoditi ekspor yang sangat berperan dalam pembangunan industri nasional. Tanaman gambir di Sumatera Barat merupakan 
pemasok komoditas ekspor ke pasar dunia. Produk gambir yang dihasilkan harus memiliki kualitas yang bagus agar tidak mengurangi nilai profit perusahaan. Permasalahan kualitas dapat mempengaruhi strategi perusahaan secara menyeluruh dalam rangka meningkatkan daya saing secara global. Pengendalian kualitas berfungsi untuk menjaga suatu sistem agar tetap efektif dalam menyatukan pengembangan kualitas, memelihara kualitas dan memperbaiki kualitas produk yang dihasilkan. (Hatani, La 2007).

Sementara pengembangan produk bertujuan untuk mempertahankan posisi perusahaan sebagai innovator dan menjaga pangsa pasar yang ada. Banyak perusahaan semakin menyadari bahwa pengembangan produk baru secara terus menerus merupakan kunci pertumbuhan dan kelangsungan hidup perusahaan (Handoko, 2012). Kualitas produk dan pegembangan produk yang dihasilkan dapat meningkatkan kepuasan konsumen. Tinggi rendahnya kepuasan konsumen disebabkan oleh dua faktor utama yaitu faktor intern dan ekstern perusahaan. Faktor intern perusahaan antara lain turunnya kualitas produk, pengembangan produk,

elayanan konsumen dan sebagainya sehingga konsumen mengalami kejenuhan atau turunnya nilai produk di pasaran. Faktor ekstern terjadi karena di luar jangkauan seperti adanya perubahan selera konsumen, kebijaksanaan pemerintah, munculnya barang pengganti dan masuknyapesaing baru.

Salah satu produsen pengolahan gambir yang ada di Sumatera Barat adalah Unit Usaha Jasa dan Industri Andalas Farma Padang yang telah berdiri pada tahun 2006. Unit Usaha Jasa dan Industri Andalas Farma Padang dalam pengendalian mutu dan pengolahan gambir memiliki mesin dan peralatan yang cukup modern pada bidang produksi. Unit ini dalam mengolah gambir menggunakan mesin modern yang sesuai dengan skala industri. Unit Usaha Jasa dan Industri Andalas Farma Padang mendapatkan pasokkan daun gambir dari petani daerah Pesisir Selatan dan untuk pengolahan serta pengembangan produk dilakukan oleh Unit Usaha dan Jasa Andalas Farma sendiri.

Permasalahan dalam penelitian ini adalah bagaimana dampak kualitas produksi dan pengembangan produk gambir dalam peningkatan kepuasan kosumen pada unit usaha jasa dan industri Andalas Farma. Tujuan penelitian ini adalah untuk mengetahui dampak kualitas produksi dan pengembangan produk gambir dalam peningkatan kepuasan kosumen pada Unit Usaha dan Jasa Andalas Farma.

\section{KAJIAN PUSTAKA DAN HIPOTESIS \\ Pengendalian Kualitas}

Pengendalian kualitas merupakan suatu sistem kendali yang efektif untuk mengkoordinasikan usaha-usaha penjagaan kualitas, dan perbaikan kualitas dalam berproduksi, sehingga diperoleh suatu hasil produksi yang sangat ekonomis serta dapat memuaskan kebutuhan dan keinginan konsumen (Prihantoro, 2012:6). Beberapa alasan mengapa pengendalian kualitas harus diterapkan, 1). Agar produk yang dihasilkan sesuai dengan spesifikasi yang telah ditentukan sebelumnya, sehingga dapat memuaskan konsumen dalam memenuhi kebutuhan dan keinginannya. 2) Kesalahan-kesalahan yang memungkinkan terjadi dapat dihindarkan sehingga akan menghemat pemakaian bahan baku, dan sumber daya lainnya, serta produk-produk yang cacat atau rusak dapat dikurangi.

Tujuan pengendalian kualitas produksi menurut (Prihantoro, 2012:2) adalah 1) agar barang hasil produksi dapat mencapai standar kualitas yang telah ditetapkan. 
2) mengusahakan agar biaya inspeksi dapat menjadi sekecil mungkin. 3) biaya desain produk rendah. Proses pengendalian kualitas tersebut dapat dilakukan melalui penerapan PDCA (plan - do - check - action) yang diperkenalkan oleh Dr. W. Edwards Deming, seorang pakar kualitas ternama berkebangsaan Amerika Serikat, sehingga siklus ini disebut siklus deming (Deming Cycle/ Deming Wheel).

Tahapan siklus PDCA (Prihantoro, 2012:2) antara lain: tahap perencanaan (plan): 1. proses yang perlu diperbaiki, yaitu proses yang berkaitan erat dengan misi organisasi dan tuntutan pelanggan, 2. menentukan perbaikkan apa yang akan dilakukan terhadap proses yang dipilih, 3. menentukan data dan informasi yang diperlukan untuk memilih proses yang paling relevan dengan perusahaan.

Tahap pelaksanaan (do) adalah: 1) mengumpulkan informasi dasar tentang jalannya proses yang sedang berlangsung, 2) melakukan perubahan, 3) kembali mengumpulkan data untuk mengetahui apakah perubahan telah membawa perbaikkan atau tidak. Tahap pemeriksaan (check) adalah menafsirkan perubahan dengan menyusun data yang sudah terkumpul dalam grafik. Tahap tindakan perbaikkan (action) antara lain: 1) memutuskan perubahan mana yang akan diimplementasikan, 2) adanya pelatihan bagi karyawan agar perubahan berjalan baik, 3) Pengkajian dan analisis.

Pengendalian kualitas harus dilakukan secara terus-menerus dan teratur, sehingga perusahaan dapat mengetahui penyimpangan yang terjadi serta bertindak untuk mengatasinya agar kualitas produk tidak mengalami penurunan.

\section{Pengembangan Produk}

Pengembangan produk adalah mengembangkan konsep produk dengan menjadikan produk yang bisa dikerjakan (Kotler dan Armstrong, 2008:309). Pengembangan produk juga merupakan suatu proses penemuan ide untuk barang dan jasa termasuk merubah, menambah atau merumuskan kembali sebagian dari sifatsifat pokok yang sudah ada dalam segi corak, merek dan kuantitas. Menurut Alma, 2013:101) tujuan pengembangan produk adalah: untuk memenuhi keinginan konsumen, menambah omzet penjualan, memenangkan persaingan, mendayagunakan sumbersumber produksi, meningkatkan keuntungan dengan pemakaian bahan yang sama, mendayagunakan sisa-sisa bahan, mencegah kebosanan konsumen dan menyederhanakan produk dan pembungkus.

Tahap-tahap pengembangan produk baru (Kotler dan Keller 2009:287-306), yaitu: 1) penciptaan ide, dimana pengembangan produk baru dimulai dengan pencarian ide yang kreatif, 2) penyaringan ide, untuk menciptakan sejumlah ide-ide yang baik dan mengesampingkan yang jelek, 3) pengembangan dan pengujian konsep, 4). pengembangan strategi pemasaran, 5). analisis bisnis, 6) Pengujian pasar

\section{Kepuasan Konsumen}

Kepuasan konsumen adalah perasaan senang atau kecewa seseorang yang muncul setelah membandingkan kinerja (hasil) produk yang dihasilkan terhadap kinerja yang diharapkan (Kotler dan Keller, 2006:177). Harapan konsumen mempunyai peran yang besar dalam evaluasi kualitas produk (barang dan jasa) dan kepuasan konsumen. Harapan konsumen pada dasarnya ada hubungan erat anatara penentuan kualitas dan kepuasan pelanggan (Tjiptono, 2008:).

\section{METODE PENELITIAN}

Metodologi penelitian yang digunakan adalah metode penelitian kualitatif adalah metode penelitian yang berlandaskan pada postpositivisme/enterpretif, digunakan untuk 
meneliti pada kondisi objek yang alamiah, analisis data bersifat kualitatif, dan hasil kualitatif lebih menekankan makna daripada generalisasi (Sugiyono,2011). Populasi yang digunakan dalam penelitian ini dibagi menjadi dua objek yaitu populasi pertama dari pihak internal merupakan aktivitas orang-orang yang ada pada Unit Usaha Jasa dan Industri Andalas Farma. Populasi kedua adalah dari pihak eksternal yaitu konsumen yang merupakan pengguna produk yang dihasilkan oleh Unit Usaha Jasa dan Industri Andalas Farma. Sampel internal adalah orang-orang yang ada pada Unit Usaha Jasa dan Industri Andalas Farma yang terlibat langsung dalam melakukan pengendalian kualitas produksi dan pengembangan produk sebanyak enam orang (pimpinan, wakil pimpinan, analis dan teknisi). Sampel eksternal adalah konsumen yang telah melakukan pembelian produk lebih dari tiga kali dan jumlah sampel yang diambil sebanyak 10 orang. Teknik pengumpulan data yang dilakukkan adalah observasi, wawancara dan dokumentasi.

Uji kredibilitas data dalam penelitian ini menggunakan triangulasi teknik (Sugiyono, 2011). Triangulasi teknik dilakukan dengan cara mengecek data pada sumber yang sama dengan teknik yang berbeda. Pengecekan data diperoleh dengan observasi, wawancara dan dokumentasi. Wawancara dilakukan pada dua objek yaitu internal (Unit Usaha Jasa dan Industri Andalas Farma) dan eksternal (konsumen yang membeli produk gambir lebih banyak atau lebih dari tiga kali).

\section{HASIL DAN PEMBAHASAN}

Pengendalian kualitas produksi Unit Usaha Jasa dan Industri Andalas Farma dimulai dengan merencanakan proses produksi dengan mengikuti standar yang sudah ada. Standar yang digunakan dalam proses produksi pengolahan gambir adalah SNI 013391-2000 dan FHI (Farmakope Herbal Indonesia) tahun 2010. Standar kualitas gambir menurut SNI 01-3391-2000 dari segi bentuk adalah memiliki bentuk yang utuh seperti silinder (memiliki diameter 3,6 cm dan tinggi $36 \mathrm{~cm}$ ) dan biskuit yang bentuk persegi sama sisi (memiliki ukuran 4x4). Dari segi warna produk gambir yang dihasilkan memiliki warna kuning sampai kuning kecoklatan untuk mutu I dan warna kuning sampai kuning kehitam-hitam untuk mutu II. Artinya produk gambir yang dihasilkan memiliki kualitas/mutu I. Standar kualitas produk gambir mutu I memiliki kadar katekin murni sebanyak 86-99\%.

Dalam menghasilkan produk gambir yang berkualitas Unit Usaha Jasa dan Industri Andalas Farma, proses produksi yang dilalui, antara lain :

Tahap Perencanaan (plan)

a. Pemilihan bahan baku

Pemilihan daun gambir yang akan diolah merupakan daun gambir pilihan yang berasal dari petani gambir yang ada di Sumatera Barat seperti Siguntur (Kabupaten Pesisir Selatan) dan Lareh Sago Halaban, Mungka dan Pangkalan Koto Baru (Kabupaten Lima Puluh Kota, Payakumbuh). 


\section{Gambar 1. Tanaman Gambir (Uncaria Gambir(Hunter) Roxb.)}

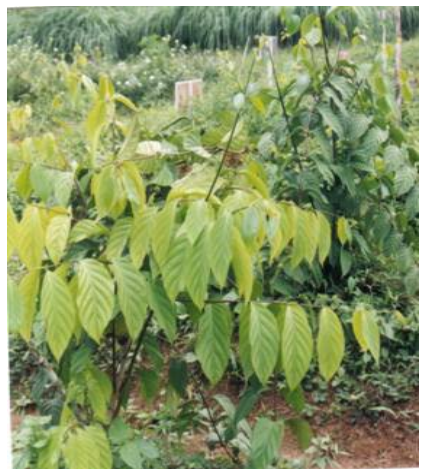

Sumber: Unit Usaha Jasa dan Industri Andalas Farma

Dalam memilih bahan baku yang akan digunakan Unit Usaha Jasa dan Industri Andalas Farma selalu mengambil daun gambir tua dan segar. Daun gambir yang tua dan segar banyak mengadung kadar katekin di bandingkan dengan daun gambir yang masih muda. Dalam pemilihan bahan baku ini dapat menentukan kualitas produk gambir yang dihasilkan. Jadi bahan baku gambir yang digunakan yang berkualitas sehingga memberikan dampak hasil gambir yang berkualitas dan tidak memiliki bau yang kurang sedap

b. Penggunaan alat produksi

Untuk menjaga kualitas hasil produksi gambir dari hasil wawancara dengan bagian teknis Unit Usaha Jasa dan Industri Andalas Farma mengatakan bahwa dalam proses produksi sudah menggunakan alat dan teknologi yang lebih modern dari alat produksi yang digunakan oleh petani gambir. Seperti alat steamer, boiler, dan kempa hidrolik, sehingga hasil produksi lebih terjaga kualitasnya Alat ini sangat efektif dan efisien dalam melaksanakan proses pengolahan gambir dibandingkan dengan alat tradisional yang digunakan oleh petani gambir yang ada di Sumatera Barat. Dengan adanya alat yang modern ini unit dapat menghemat waktu dan biaya dalam pengolahan produk gambir serta dapat menghasilkan produk yang lebih banyak.

\section{Tahap Pelaksanaan $(D o)$}

Pada tahap pelaksanaan yang dilakukan adalah melaksanakan rencana kerja yang telah disusun sebagai berikut:

\section{a. Pengukusan daun gambir}

Daun dan ranting gambir sebanyak $30 \mathrm{~kg}$ dicuci sampai bersih kemudian dimasukkan kedalam jala rajut dari plastik atau tali kulit, kemudian dimasukkan kedalam alat steamer yang pada alat boiler telah berisi air yang sudah mendidih terlebih dahulu. Lama pengukusan selama 1 jam.

Gambar 2. Alat PengukusanPucuk Daun dan Ranting Gambir

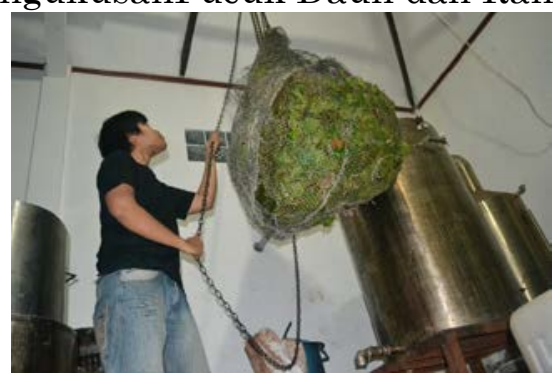


Selama kegiatan pengukusan tidak melakukan pembalikan bahan seperti yang dilakukan oleh petani gambir secara manual sehingga kerja lebih efektif. Alat yang digunakan stainlesteel yang bagus sehingga gambir yang dihasilkan lebih bersih dan bagus.

\section{b. Pengempaan/mengepres}

Tahap ini adalah tahap yang terpenting, karena pada tahap tersebut yang diharapkan adalah banyaknya hasil getah gambir setelah pengempaan. Setelah selesai dikukus dan diangkat kemudian keluarkan daun dan ranting dari jala plastik dan dimasukkan ke dalam alat kempa hidrolik agar mengeluarkan getah gambir yang banyak. Tempat yang digunakan terbuat dari stainlesteel yang juga terjaga kerbersihannya dibandingkan dengan cara manual yang dilakukan oleh petani gambir. Kegiatan ini diharapkan akan menambah kualitas gambir yang diproduksi.

\section{c. Pengendapan dan penirisan}

Tahap pengendapan dan penirisan ini adalah tahap dalam menghasilkan sebuah produk dalam suatu kegiatan proses produksi dengan cara memisahkan air dengan getah gambir. Produk yang dihasilkan dari aktivitas ini dapat memberikan profit bagi Unit Usaha Jasa dan Andalas Farma karena banyaknya jumlah gambir yang mengendap akan manambah jumlah banyaknya produk gambir yang dihasilkan. Dengan pengempaan/mengepres getah gambir dengan menggunakan alat yang modern akan dapat menghasilkan getah gambir yang banyak sehingga hasil produksi meningkat

\section{d. Pencetakan dan Pengeringan.}

Pencetakan bentuk gambir yang berkualitas di Unit Usaha dan Jasa Andalas Farma berbentuk biskuit, ini dilakukan untuk menjaga kualitas saat pembungkusan/ packing tidak rusak. Gambir yang bererdar di pasar dicetak berbentuk silinder cekung dan berbentuk koin. Pencetakkan produk gambir berhubungan dengan desain produk yang dilakukan agar produk gambir dapat memiliki nilai jual tinggi. Hal ini juga berbeda cara pencetakan yang dilakukan oleh petani gambir yang berbentuk bulat lonjong sehingga saat di packing lebih banyak rusak yang mengakibatkan kualitasnya turun sehingga juga turun

\section{Gambar 4.7 Pencetakkan dan Pengeringan Getah Gambir}

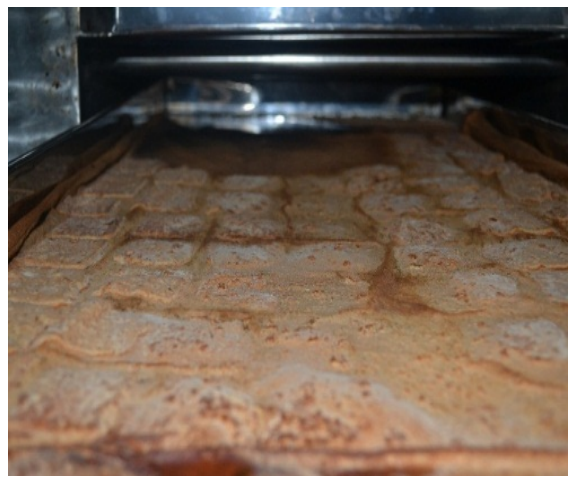

Kurang bagus

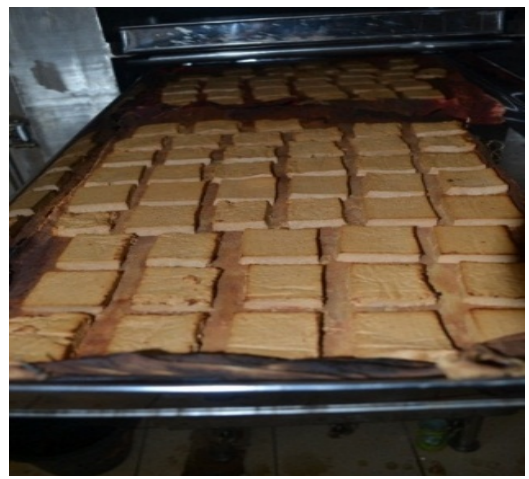

Bagus

Sumber : Hasil Observasi Bentuk cetakan gambir yang berkualitas tidak bagus dengan hasil yang bagus

Jika hasil pencetakan tidak rapi maka konsumen akan kurang puas dengan bentuk produk tersebut dan harga jualnya pun akan rendah. Hal ini disebabkan karena 
kurangnya kualitas dalam proses produksi gambir. Namun dengan proses produksi yang dilakukan di Unit Usaha Jasa dan Industri Andalas Farma maka harga gambir menjadi lebih mahal dan disukai oleh konsumen.

e. Analisis Mutu/Kualitas (SNI 2000)

Analisis mutu/kualitas produk ini bertujuan untuk melihat kepuasan (kebutuhan dan harga) yang didapatkan konsumen dari integritas produk yang dihasilkan oleh Unit Usaha Jasa dan Industri Andalas Farma. Penerapan sistem manajemen mutu/kualitas pada produk gambir ini adalah pengendalian mutu/kualitas pada aspek rancangan/desain produk, proses produksi, produktivitas dan pemasaran. Pengendalian kualitas produksi pada unit ini dilakukan berdasarkan standar SNI 01-3391-2000. Mutu merupakan hal yang terpenting dalam membangun dan mengelola fungsi produksi. Kualitas tidak hanya dilihat dari hasil produk tetapi juga kulitas manusia, kualitas proses dan kualitas lingkungan yang dapat memenuhi atau melebihi harapan konsumen.

\section{Tahap Pemeriksaan (Check)}

Unit Usaha Jasa dan Industri Andalas Farma juga melakukan uji laboratorim unit lain seperti Sucofindo, Departemen Perdagangan dan Baristand terhadap gambir yang diproduksi. Jika ada hasil produk gambir yang tidak sesuai dengan kualitas dan keinginan konsumen maka produk gambir tersebut dilakukan pengolahan ulang agar memiliki kualitas yang bagus dan dapat dipasarkan sesuai dengan selera konsumen.

Dengan adanya tahap uji laboratorium ini, gambir yang dihasilkan lebih kualitasnya sehingga harapan konsumen dapat terpenuhi untuk mendapatkan gambir yang berkualitas di Sumatera Barat. Kepercayaan konsumen sangat berharga agar dapat menjaga kelangsungan hidup perusahaan serta peningkatan profit perusahaan.

\section{Tahap Tindakan Perbaikkan (Action)}

Tahap tindakan perbaikkan merupakan tahap untuk mengambil tindakan yang seperlunya terhadap hasil-hasil dari tahap pemeriksaan (check) yang berupa solusi terhadap masalah yang dihadapi. Tindakan perbaikkan ini perlu diambil jika hasilnya tidak mencapai apa yang telah direncanakan dan ditargetkan terhadap kualitas gambir yang diinginkan.

\section{Pengembangan Produk}

Untuk pengembangan produk dapat dilakukan dengan penciptaan ide yang selalu melihat dari kebutuhan masyarakat dan mengembangkannya. Ide yang timbul berasal dari interaksi antara pimpinan dan karyawan yang dikemukakan dalam diskusi dan rapat. Perusahaan mengembangkan dan mengkonsep suatu produk yang baik dan berkualitas sehingga dapat menarik konsumen untuk membelinya. Produk gambir tidak hanya berfungsi sebagai obat-obatan (maag dan diare) tetapi dikembangkan menjadi produk kosmetik yang dibutuhkan oleh konsumen. Pengembangan produk pada Unit Usaha Jasa dan Industri Andalas Farma sebagai bahan untuk kosmestik bertujuan untuk memenuhi keinginan konsumen, meningkatkan jumlah penjualan, mendayagunakan sumber-sumber produksi yang ada dan mencegah kebosanan konsumen. Pengujian konsep produk ini dilakukan dengan pemberian sampel produk pada konsumen agar mereka lebih merasakan manfaat dari produk baru ini. Produk yang dikembangkan antara lain masker gambir, Biogam Gel (obat jerawat), masker peel off (masker wajah), Gartevit (obat kumur) dan lainnya. 


\section{Gambar 2 Pengembangan pada Produk Gambir Produksi Unit Usaha Jasa dan Industri Andalas Farma}
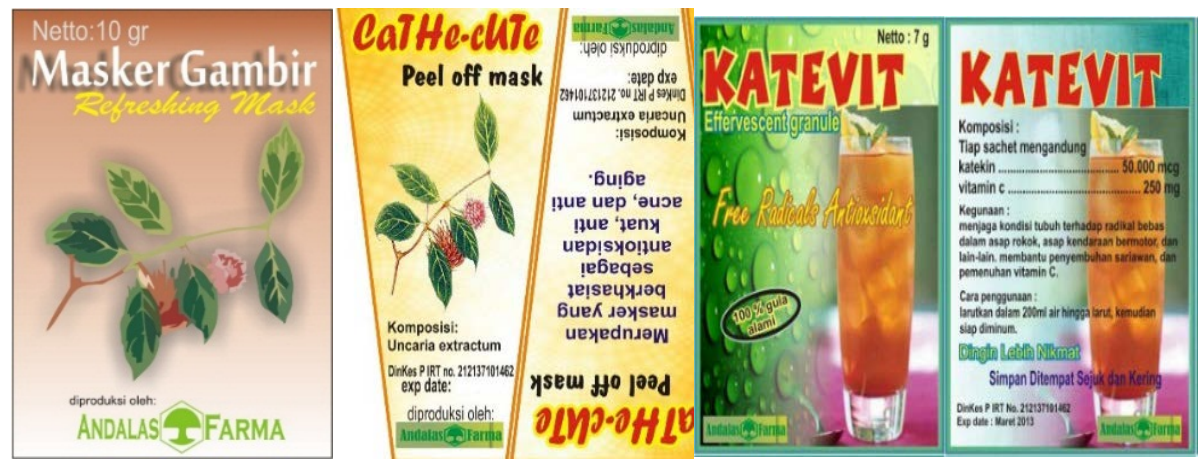

Sumber: Unit Usaha Jasa dan Industri Andalas Farma, 2017

\section{Kepuasan Konsumen}

Kepuasan konsumen merupakan konsep sentral dalam wacana bisnis dan manajemen. Peningkatan kepuasan konsumen berpotensi mengarah pada pertumbuhan penjualan jangka panjang dan jangka pendek serta pangsa pasar sebagai hasil pembelian berulang. Kesesuaian harapan merupakan tingkat kesesuaian antara kinerja produk yang diharapkan oleh konsumen membuat mereka puas setelah menggunakan produk gambir.

Dua konsumen lainnya mengatakan mereka puas dari manfaat produk yang mereka rasakan adalah setelah menggunakan produk masker gambir dan masker pell off, kulit wajah terasa halus, lembut dan meregang. Garis halus di wajah tidak tampak lagi setelah menggunakan produk ini dan mereka merasakan kenyal-kenyal pada kulit setelah menggunakan produk ini.

Mereka merasakan senang setelah membandingkan kinerja (hasil) produk yang dipikirkan terhadap kinerja yang diharapkan. Pelayanan yang diberikan oleh karyawan kepada konsumen pada saat pembelian pun membuat mereka merasa nyaman. Salah satu pelayanan yang diberikan adalah pemilihan dalam pembelian produk yang sesuai dengan kebutuhan dan pelayanan. Selain itu kepuasan juga diperoleh dengan minat berkunjung kembali semakin meningkat.

\section{PENUTUP}

Dampak pengendalian kualitas produksi gambir dan pengembangan pada Unit Usaha Jasa dan Industri Andalas Farma adalah gambir yang dihasilkan cukup berkualitas. Sedangkan pengembangan produknya adalah sebagai bahan untuk komestik. Dengan demikian gambir yang diproduksi oleh Unit Usaha Jasa dan Industri Andalas Farma tidak saja sebagai bahan untuk obat tetapi juga sebagai bahan untuk kosmestik. Saran yang dapat diberikan adalah agar jumlah produksi gambir dapat ditingkatkan sehingga dapat terpenuhi semua keinginan konsumen. Disamping itu kebersihan dalam proses produksi tetap dijaga agar kualitas tetap dikedepankan. 
Febriani, Rachmawati dan Putra/ Jurnal Manajemen, Vol 8, No 2 (2018): 88 - 96

\section{REFERENSI}

Alma, Buchari. 2013. Manajemen Pemasaran dan Pemasaran Jasa. Jakarta:Penerbit Alfabert.

Kotler, Philip dan Kevin Lane Keller, 2009. Manajemen Pemasaran, Edisi 13, Jilid 1 dan 2. Jakarta: Erlangga.

Hatani, La, 2007. "Manajemen Pengendalian Mutu Produksi Roti Melalui Pendekatan Statistical Quality Control (SQC)." Diakses 12 Maret 2010,dari www.google.com/Jurusan Manajemen FE Unhalu.

Prihantoro, Rudy, 2012. Konsep Pengendalian Mutu, Bandung: PT. Remaja Rosdakarya Offset

Putriandari, S., Aulia, 2011. Analisis Pengaruh Kualitas Jasa Dan Kepuasan Pelanggan Terhadap Loyalitas Pelanggan Pengguna Telkom Speedy Di Semarang. Fakultas Ekonomika Dan Bisnis Universitas Diponegoro Semarang.

Sugiyono. 2011. Metode Penelitian Kuantitatif Kualitatif dan R dan D.CV. Bandung: Alfabeta.

Tjiptono, Fandy. 2008. Strategi Pemasaran, Edisi Kedua. Cetakan Keenam. Yogyakarta: Penerbit Andy

Tjiptono, Fandy dan Anastasia Diana. 2008. Total Quality Manajemen, Edisi Revisi. Yogyakarta: Penerbit Andy. 